\title{
과암모니아뇌증 1예
}

\author{
을지대학교 의과대학 을지대학교병원 신경과 \\ 윤수진 · 최서영 · 김재국
}

\section{Hyperammonemic Encephalopathy with Diffuse Cortical and Thalamic Signal Changes on Diffusion-Weighted Brain MRI}

\author{
Soo Jin Yoon, MD, Seo Young Choi, MD, and Jae Guk Kim, MD \\ Department of Neurology, Eulji University Hospital, Eulji University School of Medicine, Daejeon, Korea
}

\begin{abstract}
Background: Hepatic encephalopathy is usually accompanied by high signal intensities in the bilateral globus pallidus and the cerebral peduncle on T1-weighted brain images. Here, we present a case of fulminant hepatic failure along with hyperammonemia.

Case Report: A 47-year-old man was admitted to our hospital due to decreased mental status. The laboratory tests showed increased aspartate transaminase, alanine transaminase, total bilirubin, ammonia levels and positive hepatitis A virus IgM antibody. Diffusionweighted brain imaging revealed high signal intensities in diffuse cortical areas, including the insular cortex, cingulate gyrus, and bilateral thalami. However, there was no involvement of the perirolandic area and the occipital cortex. We diagnosed the patient with hyperammonemic encephalopathy with fulminant hepatitis A infection.

Conclusion: We described a case of hyperammonemic encephalopathy with diffuse cerebral and thalamic involvement. This case emphasized the obvious implication that signal changes in the insular cortex and the cingulate gyrus could be a 'sentinel sign', and increased diffuse cortical and thalamic involvement may point to a more severe status.

J Neurocrit Care 2016;9(1):37-40
\end{abstract}

Key Words: Hyperammonemic encephalopathy; Insula; Thalamus

\section{서 론}

간성 뇌병증(hepatic encephalopathy)은 만성간염이나 간경 화, 알코올남용에 의한 만성적인 간질환의 병력이 있는 환자 에서 의식 변화나 경련발작의 신경계 증상, 혈액 검사상 간수 치 상승, 암모니아 증가, 뇌 MRI상 T2강조영상에서의 신호 변 화 없이 $\mathrm{T} 1$ 강조영상에서의 담창구(globus pallidus)와 대뇌다 리(cerebral peduncle)의 신호 강도 변화를 보이면 의심하는 질 환으로 단백질 제한 식이, 락툴로스 관장, 감염조절과 같은 보

Received: October 3, 2015 / Revised: February 3, 2016

Accepted: March 7, 2016

Address for correspondence: Soo Jin Yoon, MD

Department of Neurology, Eulji University Hospital, Eulji University

School of Medicine, 95 Doonsanseoro, Seogu, Daejeon 35233, Korea Tel: +82-42-611-3441, Fax: +82-42-611-3858

E-mail: trumind@eulji.ac.kr
전치료로 증상의 호전을 보인다. 저자들은 의식 저하로 내원한 급성 전격간염 환자에서 전형적인 간성 뇌병증의 영상 대신, 확산강조영상에서의 미만성 피질 신호 강도 변화를 보이는 과 암모니아뇌증(hyperammonemic encephalopathy) 환자 1예를 경험하여 이를 문헌 고찰과 함께 보고하는 바이다.

\section{증 례}

47세 남자 환자가 의식 저하를 주소로 응급실을 방문하였다. 내원 8 일 전부터 발열감과 근육통, 4 일 전부터 전신 위약감, 설 사, 구역, 구토, 내원 전일 몸 상태가 안 좋다며 밤에 운동을 하 였는데, 다음 날 아침 보호자가 깨워도 일어나지 않아 병원으 로 이송되었다. 환자는 B형 간염 보균자로 약 7년 전부터 매주 4-5차례, 소주 한 병씩을 마셔왔다.

응급실 도착 당시 의식은 혼미하였고, 혈압 $150 / 100 \mathrm{mmHg}$, 

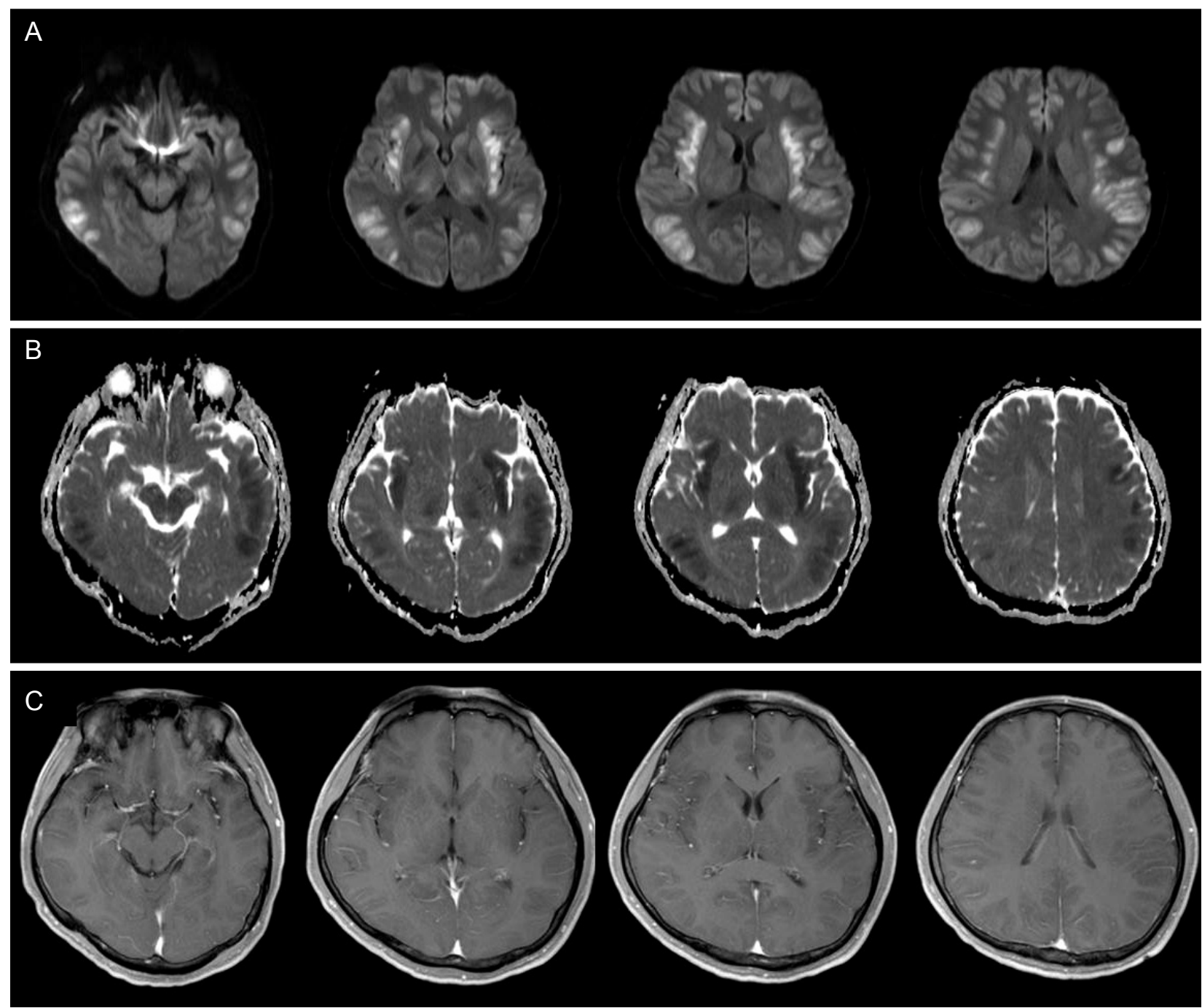

Figure 1. On admission, diffusion-weighted images and T1-weighted images revealed no abnormalities. Two days later, diffusion-weighted images (A) unveiled high signal intensities on the bilateral insular, temporoparietal, frontal cortices, and thalami. The same areas had low signal intensities on apparent diffusion coefficient map (B). No lesion enhancement or hyperintensities of the globus pallidus on T1-weighted enhanced images $(C)$ but cerebral swelling was observed.

맥박 48 회/분, 호흡 18 회/분, 체온 $36^{\circ} \mathrm{C}$ 였다. 혈액 검사상 백혈 구 수치는 $11,350 / \mu l$ 이었고, 혈소판 수치는 $58,000 / \mu \ell$ 로 감 소, AST, ALT, ALP, $\gamma$-GTP는 각각 $1755 \mathrm{IU} / \mathrm{L}, 5359 \mathrm{IU} / \mathrm{L}, 233$ IU/L, 277 IU/L로 증가, 총 빌리루빈 $11.39 \mathrm{mg} / \mathrm{dL}$, 암모니아 63 $\mathrm{uMol} / \mathrm{L}, \mathrm{PT}$ INR 4.37로 증가, 혈당 $70 \mathrm{mg} / \mathrm{dL}, \mathrm{CRP} 0.34 \mathrm{mg} / \mathrm{dL}$ 이었다. 응급실 내원시 시행한 뇌 확산강조영상과 $\mathrm{T} 1$ 강조영상 에서 이상 소견은 관찰되지 않았으나, 간성 뇌병증 의심 하에 내과 입원하여 중환자실 치료 중 신경과로 협진되었다.

환자는 피부와 공막이 노란색을 띄었고, 스스로 눈을 뜰 때도 있었으나 자극에는 반응을 보이지 않았다. 동공반사는 양측 대 칭적이었고 심부건반사는 정상이었으나, 양측에서 chaddock 징후 양성이었다. 혈액검사상 AST, ALT, ALP, $\gamma$-GTP, 총 빌리 루빈 수치는 차츰 호전을 보였으나, 암모니아는 $169 \mathrm{uMol} / \mathrm{L}$ 로
오히려 증가하였다. 내원 이틀 후 뇌 확산강조영상을 다시 시 행하였고, 양측 뇌섬엽(insular cortex)을 포함하여 전두엽, 측 두엽, 두정엽과 시상부위에서 대칭적인 고신호강도가 관찰되 었으며, 겉보기확산계수지도(apparent diffusion coefficient $\mathrm{map}$ )에서는 저신호강도를 보였고, 조영증강은 되지 않았다 (Fig. 1A, B, C).

혈액검사상 $\mathrm{HAV} \mathrm{Ab} \operatorname{IgM}(+), \mathrm{HAV} \operatorname{IgG}(+), \mathrm{HBs} \mathrm{Ag}(+), \mathrm{HBs}$ Ab (-), HBcAb Ig G (+), HBe Ag (-), HBe Ab (+), HBV DNA PCR 정량 <6 IU/mL, HCV-Ab (-), Triple Ab (-), $\alpha \mathrm{FP} 21.9$ ng/ $\mathrm{mL}$ 만성적으로 술을 마시는 B형 간염 보균자에서 급성 $\mathrm{A}$ 형 간 염으로 인한 전격간염이 고암모니아 뇌병증의 원인으로 진단 되었다. 환자는 간 이식이 필요한 상태로 전원되었다. 


\section{고 찰}

만성 간질환으로 인한 뇌 MRI 소견은 T2강조영상의 신호 변 화 없이 T1강조영상에서의 담창구와 대뇌다리에서의 신호강 도 증가가 대표적이며, 이 때 항상 혈중 암모니아 상승을 동반 하지는 않는다. ${ }^{1}$ 비록 암모니아가 간성 뇌병증 발생에 중대한 역할을 하는 것으로 알려져 있으나, 약 $10 \%$ 의 간성 뇌병증 환 자에서 혈중 암모니아가 정상 수치를 보이고 있고, 암모니아 수치가 올라간 간경화 환자에서 간성 뇌병증을 보이지 않는 경 우도 있다. ${ }^{2}$

그런데 급성 간부전 환자에서 의식장애, 경련발작, 실조증 같 은 신경학적 문제를 보이며, 혈중 암모니아 수치가 상승되고, 뇌 확산강조영상상 뇌섬엽과 띠다발이랑(cingulate gyrus)에서 의 고신호강도를 동반하는 경우 과암모니아뇌증을 고려해야 한다. ${ }^{3-7}$ 과암모니아뇌증은 전격간염으로 인한 급성 간부전, 과 다한 아세트아미노펜이나 발프로익산 등의 약물 복용이나 술 등의 독성 물질, 요로감염, 패혈증, 소화기 출혈, 자가면역 질 환, 폐나 골수 이식, 선천성 대사질환 등에서 발생한다고 보고 되어 왔다. ${ }^{5}$

간부전이 발생하면 혈중 암모니아가 상승하고 확산에 의하 여 혈액뇌장벽을 통과한 뇌 안의 암모니아도 증가한다. 암모니 아는 별아교세포에서 글루타민합성효소에 의해 글루타메이트 를 글루타민으로 대사하는 과정에 이용되는데, 뇌 안 암모니아 의 증가로 글루타민도 따라서 증가하게 된다. 글루타민은 삼투 작용으로 세포 내로 물을 끌어 당기고, 뇌부종과 두개 내 고혈 압, 뇌관류저하, 심한 경우 뇌탈출을 일으킨다. 여기에 더하여 산화 스트레스, 뇌혈류 증가, 염증성 싸이토카인 분비, 젖산 증 가, 대뇌의 자동조절 손상으로 뇌 손상이 발생한다고 한다..$^{8-11}$ 과암모니아뇌증 환자에서 왜 뇌섬엽과 띠다발이랑이 더 먼 저 쉽게 손상되는지에 대한 기전은 아직 밝혀진 바 없으나, 뇌 섬엽과 띠다발이랑을 포함한 전반적인 뇌 피질 손상을 일으킬 수 있고, 심부 회백질의 변화를 일으킬 수 있으며, 상대적으로 후두엽은 덜 침범한다고 한다. ${ }^{3,5,10,12,13}$ 과암모니아뇌증에서 관 찰되는 피질의 변화는 대개 미만성이고 대칭적이다. 만약 뇌 확산강조영상에서 뇌섬엽과 띠다발이랑뿐만 아니라 전반적인 대뇌피질의 고신호강도를 보인다면, 저산소증, 저혈당, 뇌전증 지속상태에 의한 경우를 배제하여야 한다. ${ }^{70-12,14}$

물론 대사성 질환의 진단은 단순히 뇌 영상에 의존한다기 보 다는 임상증세와 검사실 결과가 이를 뒷받침해 주어야만 하는 데, 저산소증에 의한 경우는 롤란딕 주변 부위(peri-rolandic area, sensorimotor cortices), 두정엽, 후두엽 (visual cortex), 그 리고 미상핵(caudate nucleus)을 포함한 기저핵, 시상의 심부 회색질에서 신호 변화가 자주 관찰되는 것으로 알려져 있다. ${ }^{15}$
본 증례는 만성 알코올 섭취, $\mathrm{B}$ 형간염 보균자에서 급성 $\mathrm{A}$ 형 간염으로 인하여 과암모니아뇌증이 발생한 경우로 사료된다. 임상적으로도 저산소증/허혈성 원인을 의심할만한 소견을 보 이지 않았으며, 혹시 수면 도중 발생하였을 질식에 대한 가능 성도 고려하였으나 흡인폐렴 소견은 동반하지 않았고, 임상적 으로 경련발작이나 혈액검사상 저혈당 소견 역시 동반하지 않 았다. 뇌 영상 소견 역시 롤란딕 주변 부위와 후두엽은 침범하 지 않았고, 뇌섬엽과 양측 시상의 신호변화가 관찰되어 과암모 니아뇌증에 합당한 소견으로 생각되었다.

추가적으로, 환자가 의식저하로 응급실을 방문하였을 때 시 행한 뇌 확산강조영상에서는 이상 소견이 관찰되지 않았으나, 간 손상에 대한 보존치료 이틀 후에도 환자의 의식이 회복되지 않고, 혈중 간 수치가 낮아지는데도 암모니아 수치는 지속적으 로 상승하여 재시행한 뇌 확산강조영상에서 과암모니아뇌증 의 특징적 뇌 영상소견인 양측 뇌섬엽과 시상부위 및 미만성피 질의 대칭적 이상 소견이 관찰되었다. 이는 고암모니아혈증 환 자에서 뇌 확산강조영상 변화를 보이는데 일정 시간이 소요됨 을 시사한다. ${ }^{4}$

과암모니아뇌증의 치료로는 뇌 부종을 가라앉히고 뇌탈출 발생을 억제하기 위해 만니톨을 사용하거나, 항생제와 항진균 제 사용으로 기저 감염을 치료하고 면역저하 상태로 인한 중복 감염을 예방하는 것이 중요하다. ${ }^{8}$ 또한, 암모니아 생산을 차단 하기 위해 단백질 섭취를 제한시키며, 궁극적으로 간이식을 기 다리는 동안 혈액투석이나 복막투석을 통해 암모니아를 제거 해야 한다. ${ }^{8}$ 저체온 요법도 고암모니아혈증의 치료가 될 수 있 는데 뇌부종과 간성 뇌병증의 기간을 감소시키는 것으로 알려 져 있고, 이는 뇌혈류와 자동조절을 개선시키고 단백질 대사를 늦추어 암모니아 생산을 감소시킨다고 한다. ${ }^{2,8}$

과암모니아뇌증은 사망률이 $50 \%$ 에 이를 정도로 치명적인 결과를 초래하기 때문에 뇌 확산강조영상에서 뇌섬엽, 띠다 발이랑, 피질, 시상 부위에서의 신호 변화를 보이는 과암모니 아뇌증의 경우 응급집중치료의 대상이다. ${ }^{12}$ 또한 질환의 급성 기 과암모니아뇌증이 의심된다면, 처음 뇌 확산강조영상 결 과가 음성이더라도 뇌 영상 재검을 고려해야 할 것으로 여겨 진다.

\section{Acknowledgements}

This research was supported by the Original Technology Research Program for Brain Science through the National Research Foundation of Korea (NRF) funded by the Korean government (MSIP) (No. 2014M3C7A1064752). 


\section{REFERENCES}

1. Rovira A, Alonso J, Cordoba J. MR imaging findings in hepatic encephalopathy. AJNR Am J Neuroradiol 2008;29:161221.

2. Cichoz-Lach H, Michalak A. Current pathogenetic aspects of hepatic encephalopathy and noncirrhotic hyperammonemic encephalopathy. World J Gastroenterol 2013;19:26-34.

3. McKinney AM, Lohman BD, Sarikaya B, Uhlmann E, Spanbauer J, Singewald T, et al. Acute hepatic encephalopathy: diffusion-weighted and fluid-attenuated inversion recovery findings, and correlation with plasma ammonia level and clinical outcome. AJNR Am J Neuroradiol 2010;31:1471-9.

4. Capizzano AA, Sanchez A, Moritani T, Yager J. Hyperammonemic encephalopathy: time course of MRI diffusion changes. Neurology 2012;78:600-1.

5. Rosario M, McMahon K, Finelli PF. Diffusion-weighted imaging in acute hyperammonemic encephalopathy. Neurohospitalist 2013;3:125-30.

6. Zhang LJ, Zhong J, Lu GM. Multimodality MR imaging findings of low-grade brain edema in hepatic encephalopathy. AJNR Am J Neuroradiol 2013;34:707-15.

7. Sureka J, Jakkani RK, Panwar S. MRI findings in acute hyperammonemic encephalopathy resulting from decompensated chronic liver disease. Acta Neurol Belg 2012;112:221-3.

8. Clay AS, Hainline BE. Hyperammonemia in the ICU. Chest 2007;132:1368-78
9. Singh S, Mondal P, Trigun SK. Acute liver failure in rats activates glutamine-glutamate cycle but declines antioxidant enzymes to induce oxidative stress in cerebral cortex and cerebellum. PLoS One 2014;9:e95855.

10. Takanashi J, Barkovich AJ, Cheng SF, Kostiner D, Baker JC, Packman S. Brain MR imaging in acute hyperammonemic encephalopathy arising from late-onset ornithine transcarbamylase deficiency. AJNR Am J Neuroradiol 2003;24:390-3.

11. JM UK-I, Yu E, Bartlett E, Soobrah R, Kucharczyk W. Acute hyperammonemic encephalopathy in adults: imaging findings. AJNR Am J Neuroradiol 2011;32:413-8.

12. de Havenon A, French K, Ansari S. Extensive cortical diffusion restriction in a 50-year-old female with hyperammonemic encephalopathy and status epilepticus. Case Rep Neurol Med 2014;2014:257094.

13. McKinney AM, Sarikaya B, Spanbauer J, Lohman BD, Uhlmann E. Acute hepatic (or hyperammonemic) encephalopathy: diffuse cortical injury and the significance of ammonia. AJNR Am J Neuroradiol 2011;32:E142; author reply E143.

14. Konaka K, Miyashita K, Naritomi H. Changes in diffusionweighted magnetic resonance imaging findings in the acute and subacute phases of anoxic encephalopathy. J Stroke Cerebrovasc Dis 2007; 16:82-83.

15. Howard RS, Holmes PA, Siddiqui A, Treacher D, Tsiropoulos I, Koutroumanidis M. Hypoxic-ischaemic brain injury: imaging and neurophysiology abnormalities related to outcome. QJM 2012;105:551-61. 